\title{
Simulation of Hydrogen Purification using Two Bed System Pressure Swing Adsorption
}

\author{
Vibianti Dwi Pratiwi ${ }^{1}$, Juwari ${ }^{1}$, and Renanto Handogo ${ }^{1}$
}

\begin{abstract}
Hydrogen has various functions in chemical ind ${ }^{1}$ ustries, as an agent of organic compounds synthesis, a reactant in hydrocracking, hydroalkelation, and hydrodesulfurization process in petrochemical industry, a reactant in hydrogenated fat process, a reductant agent in material industry, methanol production, silicon manufacture. Therefore, hydrogen purification is very important process for the industry processes. Pressure Swing Adsorption (PSA) is commonly used hydrogen purification process. Different utility used for hydrogen purification using PSA will change adsorbent's capacity and pressure to separate the mixture of gas into desirable components. In this study, pressure is varied from 2 to 10 bar and adsorbents are used silica gel and activated carbon. Hydrogen purification using two beds system PSA is simulated using Aspen Adsorption software. Based on the simulation result, it can be concluded that the pressure that gives most steady system is at 7 bar, which produces $99,92 \%$ hydrogen purity using activated carbon in bed 1 and silica gel in bed 2.
\end{abstract}

Keywords -Hydrogen Purity, Two Bed Adsorption, Pressure Swing Adsorption, Aspen Adsorption

\section{INTRODUCTION}

In the last years, the need for alternatives to fossil fuel has been explored due to environmental concerns. In order to be significants, an alternative fuel has to be technically feasible, economically competitive, environmentally satisfactory and readily accessible. Lately, hydrogen has been extensively explored as an alternative source of energy due to its features. Hydrogen has a higher spesific energy content, when compared with the other fuels and is widely used in numerous chemical process industries [1].

Hydrogen is an abundant element in the earth but in the form of a gaseous compound of $\mathrm{H}_{2}$ very rarely available in nature. The use of hydrogen have been developed as a source of energy either for fuel vehicles, a power plant, as well as rocket fuel. Hydrogen as fuel has better property than conventional fuel, for example, the energy generated is higher and not producing pollution [2]. In addition, hydrogen can be used in industry as a synthesis agent of organic compounds, a catalyst for production process of hydrogenated fat in food and beverages industry, production of silicon and many more[3].

Energy derived from fossils including energy is not sustainable that the less [4]. Based on data from Badan Pusat Statistik Indonesia, imported products hydrogen in Indonesia increased every year. In 2008 increased 2.724 tons of the year 2007 the volume of hydrogen increase in 2010 to within 3530 tons of the year 2009. In 2013 recorded imports hydrogen reached 39.921 tons [5]. Various kinds of processes that can be used for the production of hydrogen of any raw materials. That results hydrogen the largest of a steam reforming, autothermal reforming and catalytic partial oxidation that uses natural gas or coal bed metane to produce cost hydrogen fuel 6.26 (\$/GJ) [2].

Some industrial process need hydrogen with purity more than $99 \%$. Many technique separation to purify hydrogen. Purification that uses cryogenic separation and diffusion of polymer membrane produce hydrogen with under $98 \%$ purity. To reach above $99 \%$ purity, pressure swing adsorption (PSA) method or catalytic purification can be used [6]. PSA is the most often used process in hydrogen purification, and developed into multi-bed process by combining different absorbent in each column at a step pressure equalization [7].

The pressure swing adsorption (PSA) process has become a widely used unit operation or purification. Due to increasing demand of hydrogen for petroleum refinery and petrochemical processing, a strong economic motivation has prompted the development of processes to recover hydrogen from steam reformer off gas, catalytic reformer off gas, ad ethylene plant effluent gas [8].

The problems found in the research are how to make a simulation model for pressure swing hydrogen purification using Aspen Adsorption software while considering many aspects: equipment operating conditions and adsorbent used by PSA. These considerations are calculated for energy savings from additional utility, related to time and expenses required for the desired end products. To understand and develop the hydrogen PSA process, the researchers studied the effects of many operating parameters and manipulated parameter as pressure and adsorbent.

However, only few studies have been focused on controlling hydrogen impurity for fuel-cell application. Moreover, the optimization work is necessary for PSA system due to the complicated nature of dynamic cyclic process, and the fact that there are a large number of design parameters, such as step times, pressure, temperature, gas velocity, and bed dimennsions, which can affect PSA separation performance [9]

\section{METHOD}

This study also aims to understand equipment's operating conditions and adsorbent used in PSA design, therefore it can save energy from additional utility and expenses

${ }^{1}$ Vibianti Dwi Pratiwi, Juwari, and Renanto Handogo are with Departement of Chemical Engineering, Institut Teknologi Sepuluh Nopember, Surabaya, 60111, Indonesia, Email: vibiantidwi@yahoo.co.id; joecheits@yahoo.co.id; renanto@chemeng.its.ac.id 
required for the desired products. Thermodynamic package used in research is Peng-Robinson, which is suitable for gas separation. This research uses research by Jaeyoung Yang and Chang Ha Lee (1997) [8] as validation for the process applied in to the Aspen Adsorption software.
Validation simulation this process be useful to know the feasibility of PSA in the hydrogen purify process. The scheme diagram of PSA system for validation that can be seen from Figure 1.

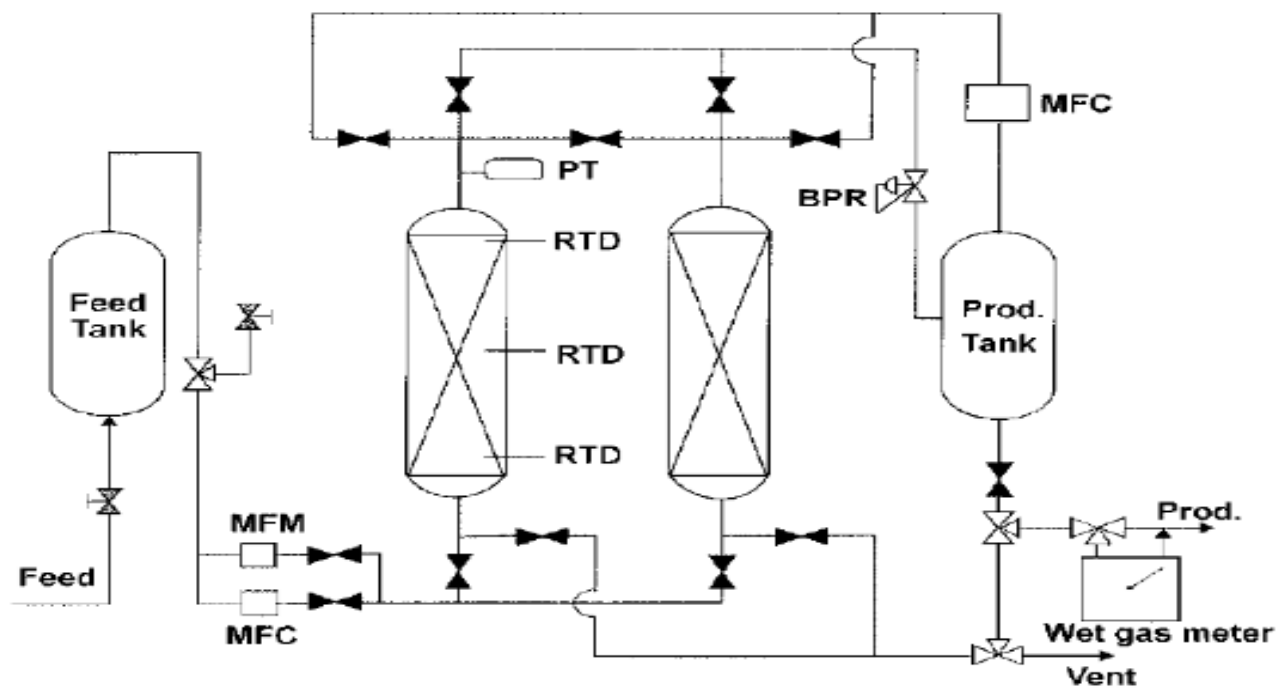

Figure 1. Scheme of Pressure Swing Adsorption

Gas separated is a mixture of methane, carbon monoxide $(\mathrm{CO})$, carbon dioxide $\left(\mathrm{CO}_{2}\right)$, hydrogen $\left(\mathrm{H}_{2}\right)$ and nitrogen $\left(\mathrm{N}_{2}\right)$. The data for feed composition on Table 1 that being used. Two bed adsorbers are used to determine hydrogen purification using simulation.
The characteristics of adsorption bed data and adsorbent input into Aspen Adsorption are shown in the Table 2. At this stage the results simulated dynamic state using Aspen Adsorption offer the same results on the condition in research.

TABLE 1.

FEED COMPOSITION

\begin{tabular}{cc}
\hline \hline Component & Compotition \\
\hline $\mathrm{CH}_{4}$ & 0,266 \\
$\mathrm{CO}$ & 0,084 \\
$\mathrm{CO}_{2}$ & 0,031 \\
$\mathrm{H}_{2}$ & 0,564 \\
$\mathrm{~N}_{2}$ & 0,055 \\
\hline Total & 1 \\
\hline
\end{tabular}

TABLE 2.

CHARACTERISTICS BED ADSORPTION DAN ADSORBENT

\begin{tabular}{c|ccc}
\hline \hline Characteristics & Spesification & Value & Units \\
\hline \multirow{5}{*}{ Bed Adsorption } & bed density & 746 & $\mathrm{~kg} / \mathrm{m}^{3}$ \\
& Void fraction & 0,35 & $\mathrm{~m}^{3} \mathrm{void} / \mathrm{m}^{3} \mathrm{bed}$ \\
& Total void fraction & 0,76 & $\mathrm{~m}^{3} \mathrm{void} / \mathrm{m}^{3} \mathrm{bed}$ \\
& Bed lenght & 100 & $\mathrm{~cm}$ \\
& Collumn heat capacity & 0,119977 & $\mathrm{cal} / \mathrm{gm} / \mathrm{k}$ \\
& Collumn wall thickness & 0,00134 & $\mathrm{~m}$ \\
\hline \multirow{5}{*}{ Adsorben } & Particel radius & 0,00157 & $\mathrm{~m}$ \\
& Particle porosity & 0,65 & $\mathrm{~m}^{3} \mathrm{void} / \mathrm{m}^{3} \mathrm{bead}$ \\
& Particle density & 1160 & $\mathrm{~kg} / \mathrm{m}^{3}$ \\
& Heat capacity & 0,219953 & $\mathrm{cal} / \mathrm{gm} / \mathrm{k}$ \\
\hline \hline
\end{tabular}


The simulation using data, information, parameters, and operating conditions in research for validation process. When the dynamic state simulated using Aspen Adsorption offer the same results on the condition in field, so design of PSA can be monitored by Aspen Adsorption. Pressure and adsorbent are manipulated variable for this study. Pressure is varied from 2 to 10 bar and adsorbents use silica gel and activated carbon in two bed adsorbers PSA.

\section{DISCUSSION}

The PSA process for hydrogen purification utilizes different loading capacities of adsorbent at different pressures to separate a gas mixture into its components. The loading capacity of an adsorbent is the amount of gas that can be bound by mass unit of the adsorbent material. The extent to which an adsorbent material. The extent to which an adsorbent can be loaded increases in general with the partial pressure of gas component [10]

This research aims to determine the influence of pressure and type of adsorbent for adsorbing impurities in hydrogen purifying process. Figure 2 shows the simulation of hydrogen purification using Aspen Adsorption.

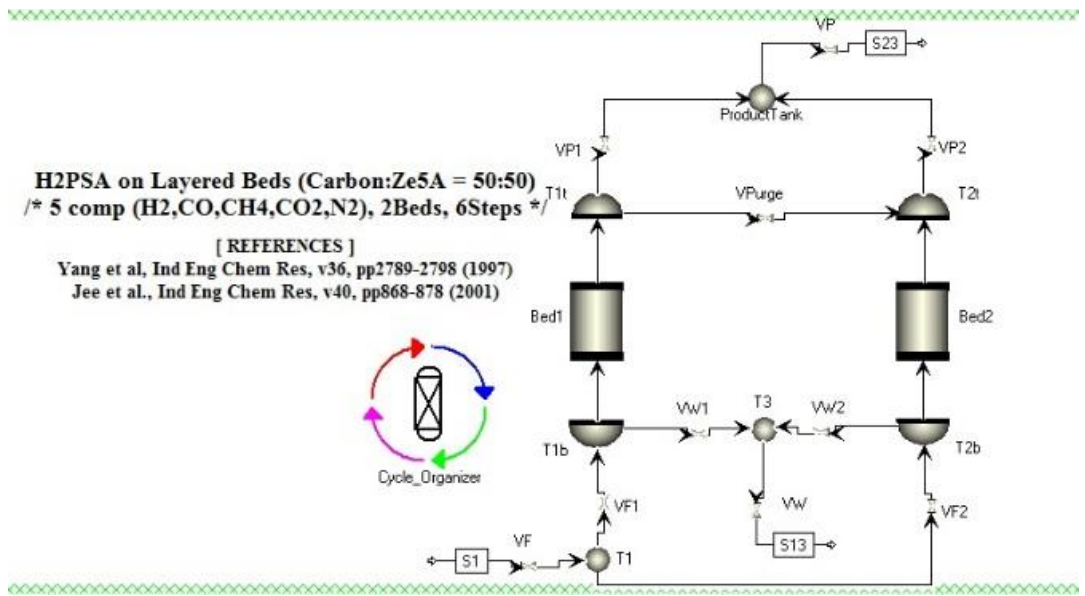

Figure 2. Validation for Process Simulation of Hydrogen Purification

TABLE 3.

RESULT OF VALIDATION FOR PROCESS SIMULATION USING ASPEN ADSORPTION

\begin{tabular}{ccc}
\hline \hline $\mathrm{P}($ bar $)$ & $\mathrm{H}_{2}(\%)$ & $\mathrm{CO}_{2}(\%)$ \\
\hline 2 & $95,12 \%$ & $1,22 \%$ \\
4 & $99,74 \%$ & $0,23 \%$ \\
5 & $99,78 \%$ & $0,20 \%$ \\
6 & $99,78 \%$ & $0,20 \%$ \\
7 & $99,79 \%$ & $0,20 \%$ \\
8 & $99,76 \%$ & $0,22 \%$ \\
9 & $99,74 \%$ & $0,25 \%$ \\
10 & $99,72 \%$ & $0,27 \%$ \\
\hline \hline
\end{tabular}

When a gas mixture containing hydrogen enters the adsorbent bed at high pressure, most components are moved by the adsorption force to the adsorbent surface and bound to the adsorbent. The adsorbed gas components concentrate on the adsorbent surface while the lighter components, such as hydrogen, are not bound thighly to adsorbent materials, and pass the adsorbent bed without sigificant interaction [10]

In a dynamic adsorption system, the better adsorbed components move slower through the adsorbent bed than the less adsorbeb. By this, the concentration of impurities in processed gas is reduced while flowing through the adsorbent bed, which result in the desired separation of stream components [10]. Simulation in this study that been validated using data from the research [8] with changes in pressure varying seen in Table 3.

Variation the pressure follow the research having range 2 bar until 10 bar. In Figure 3, validation results show that the hydrogen purity obtained using the software Aspen Adsorption approach to research. Based on the results of simulation seen from the Figure 3 can be said that the pressure most steady in purify hydrogen to pressure 7 bar. Under pressure 7 bar show purity hydrogen are getting down because approaching atmospheric pressure. But it becomes adsorption up pressure on 7 bar, then purity hydrogen declining. 


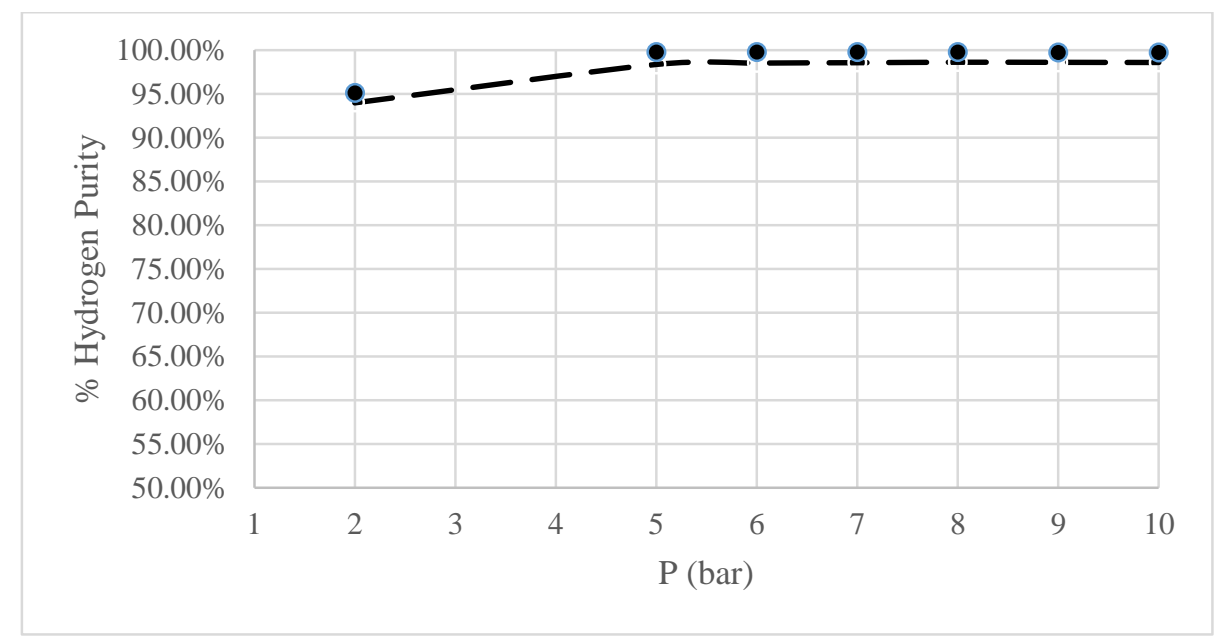

Figure 3. Result Of Validation For Process Simulation

(• Experimental and - - Jae \& Cang (1997) )

The effect of pressure adsorption in Figure 3 above shows that purity hydrogen will decline fast enough to pressure about 7 bar and recovery hydrogen which are getting down as pressure which the lower. The recovery hydrogen because loss of hydrogen for depressurization pressure. In general, the more process emulation pressure on the process of PSA will reduce gas loss wasted into the atmosphere. However this condition bed adsorption need more so will increase operating expenses to produce purity hydrogen.

Commercially avalable adsorbents are granulates, beads or extrudes. Common to all adsorbents materials is porous structure resulting in large surface. Through these pores, the moleculess move to the internal surfaces, where they are adsorbed. Any adsorbent material has specific binding capacities for different gas components [10]. Therefore, adsorber beds are designed with up to two layers of different adsorbent materials to separate hydrogen from the mixture of various gases.

Bed pressure and adsorbent type used have significant effect in hydrogen purification process by PSA. Pressure variation and type of adsorbent in two bed without combination in bed 1 and bed 2 is shown on Table 4 .

Based Table 4, the highest purity produced using two same adsorbents inside two beds is $99.88 \%$ at 4 bar using activated carbon. Hydrogen purification using activated carbon give higher purity than hydrogen purification using silica gel. The highest purity while using silica gel is $99.03 \%$ at 2 bar.

TABLE 4.

HYDROGEN PURITY VARIATION FOR TWO BED

\begin{tabular}{ccc}
\hline \hline $\mathrm{P}($ bar $)$ & Silica gel & Activated carbon \\
\hline 2 & $99.03 \%$ & $87.95 \%$ \\
4 & $88.33 \%$ & $99.88 \%$ \\
6 & $88.30 \%$ & $99.84 \%$ \\
7 & $88.30 \%$ & $99.82 \%$ \\
8 & $67.99 \%$ & $99.80 \%$ \\
10 & $63.39 \%$ & \\
\hline \hline
\end{tabular}

TABLE 4.

VARIATION OF PRESSURE AND ADSORBENT FOR HYDROGEN PURIFICATION

\begin{tabular}{|c|c|c|}
\hline$\overline{\mathrm{P}}$ & Silica gel/ Activated carbon & Activated carbon/ silica gel \\
\hline 2 & & 67.96 \\
\hline 4 & 99.86 & 65.86 \\
\hline 6 & 78.82 & 99.78 \\
\hline 7 & 99.78 & 99.92 \\
\hline 8 & 99.76 & 99.90 \\
\hline 10 & 74.04 & 64.49 \\
\hline
\end{tabular}

The relationship between the stuff that can be adsorp with temperatures and concentration can be given a chart known as isotherm adsorption. On the temperature fixed number of whose molecules can be adsorp at a surface dependent on gas pressure or concentration of solutions. The first item on a system design PSA is to choose adsorbent. For the next isoterm be relevant and other property with estimate recovery intended products on various pressure operation (assuming that purity products is optimum), and finally estimated the cost adsorbent the total cost. 
Mario I [11] have concluded that granular shaped activated carbon can be a good adsorbent because it decreases pressure in adsorption tank. When being adsorbed in activated carbon, hydrogen phase will change from a gaseous to liquid phase. It can decrease the pressure but keeping the storage capacity the same or increase storage capacity but keeping the pressure the same.

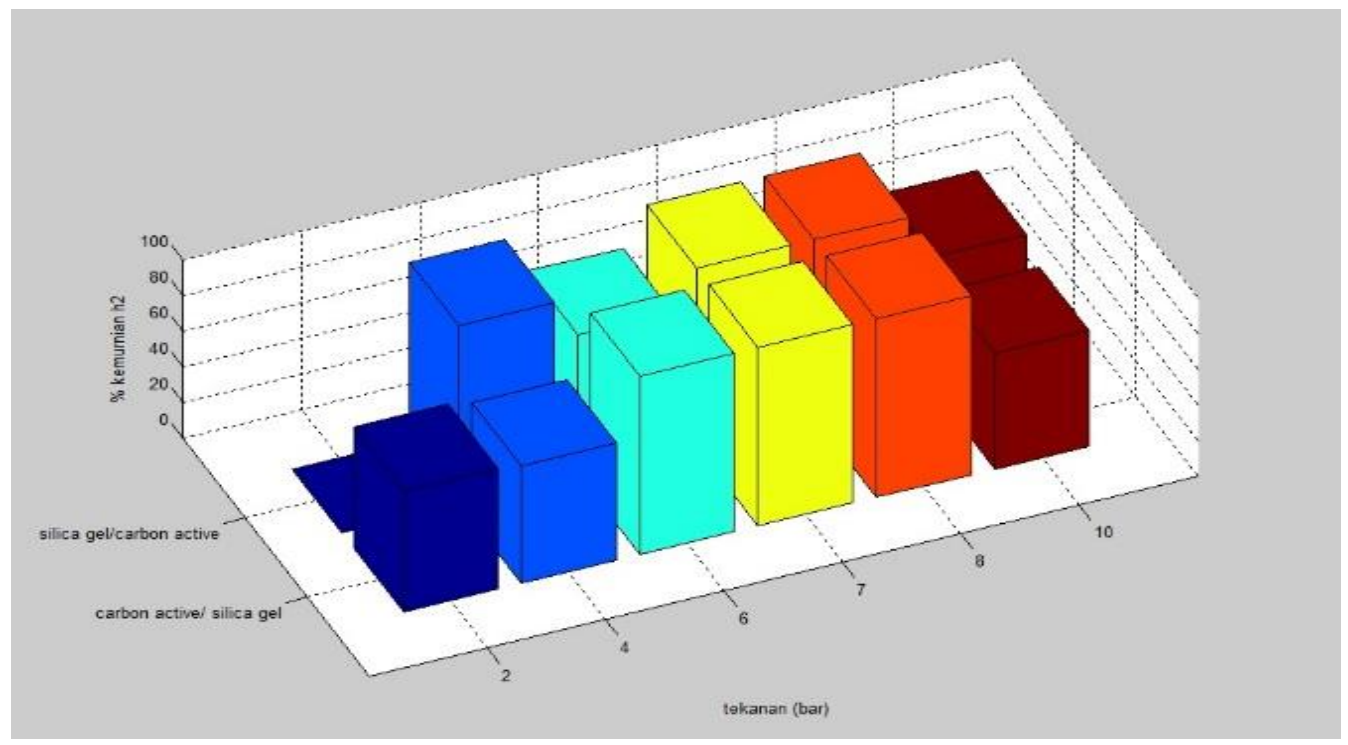

Figure 4. Hydrogen Purification Simulation Result, Displayed In 3D Diagram.

The highest hydrogen purity in combination of activated carbon or silica gel bed is produced at 7 bar pressure. Activated carbon absorbent put on bed 1 and silica gel put on bed 2 to produce hydrogen purity of $99.92 \%$. In Figure 4, it is shown the result of simulation of hydrogen purification displayed in 3D diagram. Research of Jaeyoung Yang and Chang Ha Lee (1997) [8] using activated carbon in PSA hydrogen purification, while in this research we use activated carbon or zeolite absorbents.

Based from research [12], more than two different adsorbents are applied to many PSA processes due to adsorption affinity differences among the adsorbents. To produce one high purity product from a multi-component feed, layered beds, in which two different adsorbents are superimposed on one other, are applied to the processes with great efficiency.

In pratical application, many PSA processes with layered beds have included a guard to prevent detrimental impurities from entering the main layered bed. In the PSA process with layered bed, the bottom layer works as a bulk separator, and the top layer purifies the raffinate stream from the separator layer [12].

\section{CONCLUSION}

From simulation result, it is shown that adsorbent type combination that gives the best result is activated carbon and silica gel that produces $99.92 \%$ purity with 7 bar bed pressure.

\section{REFERENCES}

[1] Franco. C. R. S., "Pressure Swing Adsorption for Hydrogen Purification”, Portugal: Universidade Do Porto, 2014.
[2] Widhiastuti. F., \& Biansha. F., "Pra Desain Pabrik Hidrogen dari Coal Bed Methane", Surabaya: Institut Teknologi Sepuluh Nopember, 2014.

[3] Adhinata. F., \& Fauziyah. M., "Pra Desain Pabrik Hidrogen dari Batubara", Surabaya: Institut Teknologi Sepuluh Nopember, 2015.

[4] Siregar, Y D I., Produksi Gas Hidrogen dari Limbah Aluminium, Jurnal Valensi, Vol. 2 No. 1 Hal. 362-367, ISSN : 1978 - 8193, 2010.

[5] BPS, Administrator., Komoditi Ekspor-Impor. http://www.bps.go.id/. Accsessed on Wednesday, October $8^{\text {th }}$ 2014.

[6] Lin Lin., "Numerical Simulation of Pressure Swing Adsorption Process", China: Xidian University, 1997.

[7] Majlan Edy H., Wan Daud Wan R., Iyuke Sunny E., Mohamad Abu B., Kadhum Amir H., Mohammad Abdul W., Takriff Mohd. S., and Bahaman N., "Hydrogen purification using compact pressure swing adsorption system for fuel cell", International Journal Of Hydrogen Energy, Vol. 34, pp. 2771-2777, 2009.

[8] Yang Jaeyoung, Lee Chang Ha dan Chang Jay Woo, "Separation of Hydrogen Mixtures by a Two-Bed Pressure Swing Adsorption Process Using Zeolite 5A", Ind. Eng. Chem. Res. Vol. 36 hal. 2789-2798, 1987.

[9] Huang. Q and Mladen. E, "Simulation of Hydrogen Purification by Pressure Swing Adsorption", Canada: University of New Brunswick, 2010.

[10] Biswas P., Agrawal S., dan Sinha S., "Modeling and Simulation for Pressure Swing Adsorption System for Hydrogen Purification”, Chem. Biochem. Eng. Q. Vol. 24(4), hal. 409-414, 2010.

[11] Mario I., "Analisa Kapasitas Penyerapan Hidrogen pada karbon Aktif Berbahan Dasar Batok Kelapa Granular dengan Pendekatan Persamaan Adsorpsi Isotermal”, Depok: Universitas Indonesia, 2012.

[12] Sol, A., Geun, L. D., You, Y. W., Hyun, K. K., Min, O., \& Ha, L. C., Layered Two- and Four- Bed PSA Processes for Hidrogen Recovery from Coal Gas, Chemical Engineering Science, 413423, 2012. 